\title{
Conservation Units as a protection tool for social wasps in Minas Gerais state, Brazil
}

\author{
Glauco Cássio de Sousa Oliveira'; Nathália Ribeiro Henriques²; Mateus Aparecido Clemente ${ }^{3}$ \& Marcos Magalhães de Souza ${ }^{4}$
}

1 Universidade Federal de São João del-Rei (UFSJ), Departamento de Ciências Naturais (DCNAT), Programa de Pós-Graduação em Ecologia. São João del-Rei, MG, Brasil. ORCID: http://orcid.org/0000-0001-9811-8485. E-mail: glaucomlds@hotmail.com (corresponding author)

2 Universidade Federal de Minas Gerais (UFMG), Instituto de Ciências Biológicas (ICB), Departamento de Genética, Ecologia e Evolução (GEE), Programa de Pós-Graduação em Ecologia, Conservação e Manejo da Vida Silvestre (ECMVS). Belo Horizonte, MG, Brasil. ORCID: http://orcid.org/0000-0002-3858-8423. E-mail: h.nathaliaribeiro@gmail.com

3 Universidade Estadual Paulista "Júlio de Mesquita Filho" (UNESP), Instituto de Biociências, Departamento de Zoologia. Rio Claro, SP, Brasil. ORCID: http://orcid.org/0000-0003-4969-1335. E-mail: mateus1981@gmail.com

${ }^{4}$ Instituto Federal de Educação, Ciência e Tecnologia do Sul de Minas (IFSULDEMINAS). Inconfidentes, MG, Brasil. ORCID: http://orcid.org/0000-0003-0415-1714. E-mail: marcos.souza@ifsuldeminas.edu.br

\begin{abstract}
Conservation Units are an important tool for the Brazilian biota protection. However, various taxa, including the social wasps, are undersampled or are unknown in these areas. Therefore, our study aimed to assess the social wasp richness and distribution in the Conservation Units in Minas Gerais state, southeastern Brazil. The social wasps were sampled between 2015 and 2019 in the Ritápolis National Forest (FLONA Ritápolis), in the Alto-Montana Private Natural Heritage Reserve (RPPN Alto-Montana), in the Rio Machado Basin State Environmental Protection Area (APA Rio Machado) and in the Serra de São José Environmental Protection Area (APA Serra de São José), using two different sampling methodologies. Fourteen species were sampled for FLONA Ritápolis, 10 for RPPN Alto-Montana, 35 for APA Rio Machado and 19 for APA Serra de São José. Ninety-six social wasp species of the known richness in Minas Gerais were sampled in 14 Conservation Units, representing $90 \%$ of the fauna of the state. Thirty-four species are exclusive to these areas, with emphasis on the Rio Doce State Park, the Serra do Papagaio State Park, the Pandeiros River Wildlife Regufe and the APA Rio Machado. Most of the Conservation Units sampled are in the Atlantic Forest areas, but further efforts are needed in this biome, because of its accelerated destruction. There is still an urgent need for more studies in the Cerrado and Caatinga areas in the state, especially in Conservation Units.
\end{abstract}

Keywords. Atlantic Forest; Caatinga; Cerrado; Insect conservation; Wasp distribution.

\section{INTRODUCTION}

Brazil harbors one of the greatest biodiversity in the entire world and, unfortunately, habitat destruction is threatening its environmental richness in a dangerously fast way. More than ever, it is essential that efforts are made for species preservation and the role of the Conservation Units becomes more important (Siqueira et al., 2017; Steinke et al., 2018). There are about 2,446 Brazilian Conservation Units covering around 1.6 million $\mathrm{km}^{2}$ on continental areas, and their main purpose is nature protection, including species, landscapes and any resources and ecosystem services (MMA, 2019). Conservation Units are distributed into five categories of fully protected areas (Ecological Station, Biological Reserve, Park, Natural Monument and Wildlife Refuge), and seven of sustainable use protected areas (Environmental Protection Area, Area of Relevant Ecological Interest, Forest, Extractive Reserve,
Fauna Reserve, Private Natural Heritage Reserve and Sustainable Development Reserve). They cover about $18 \%$ of the national territory, but only $6 \%$ of these are fully protected areas (Schiavetti et al., 2013; MMA, 2019).

Minas Gerais state is extremely biodiverse and exhibits two main biomes, the Cerrado and the Atlantic Forest, in addition to a smaller portion of the Caatinga biome, and there are about 120 public Conservation Units for both fully protected and sustainable use areas in the state (IEF, 2019; ISA, 2020). The Cerrado and the Atlantic Forest biomes are recognized for their great fauna and flora richness, several endemic and endangered species, in addition to being both worldwide biodiversity hotspots (Brooks et al., 2002; Siqueira et al., 2017; Steinke et al., 2018), harboring a great insect variety and, among them, the social wasps.

In Brazil, 365 species of social wasp (Prezoto et al., 2020; Souza et al., 2020a) belonging to three tribes on the subfamily Polistinae (Hymenoptera: 
Vespidae): Mischocyttarini, Polistini and Epiponini (Carpenter, 2004) are reported. The country is home of the higher richness of Polistinae in the world, representing more than $40 \%$ of the total richness. Social wasps are of great ecological importance since they act as bioindicators and performed various ecosystem services, behaving as predators, floral resource robbers and even as pollinators (Somavilla et al., 2017; Souza et al., 2017 and references therein). This is a very abundant insect group and at least $30 \%$ of the known native species richness was sampled in Minas Gerais state (Souza et al., 2017).

Species distribution is important for defining conservation priorities based on species that need greater protection (endemic, threatened and rare species), in addition to contribute to the biodiversity knowledge of the ecosystem (Elpino-Campos et al., 2007). Knowledge of richness, abundance and occurrence of communities is also essential to support future research, since they provide basic important data. Although species surveys are encouraged and social wasps are a relatively well-sampled group in Minas Gerais state (Barbosa et al., 2016; Souza et al., 2017), there is a need for further investigation in Conservation Units, especially considering that only about $10 \%$ of them were studied so far for this insect group.

Therefore, the aim of our study was to provide a macroecological approach on the knowledge of social wasp species in Conservation Units in the state of Minas Gerais, assessing the species richness and distribution through the review and grouping of data from articles, and inclusion of unpublished data in order to highlight the importance of Conservation Units for social wasp species.

\section{MATERIAL AND METHODS}

\section{Study area and data sampling}

Our study presents unpublished data from social wasp surveys in three Conservation Units in Minas Gerais state, Brazil (Fig. 1): the first fauna inventory for the Ritápolis National Forest, the first insect inventory for the Alto-Montana Private Natural Heritage Reserve, and the first wasp inventory for the Rio Machado Basin State Environmental Protection Area. In addition, we present an update of the species list of the Serra de São José Environmental Protection Area to the previously published by Souza et al. (2010).

Ritápolis National Forest (FLONA Ritápolis, $21^{\circ} 03^{\prime} 30^{\prime \prime} \mathrm{S}$, $44^{\circ} 16^{\prime} 25^{\prime \prime} \mathrm{W}$ ) is the smallest Conservation Unit in Minas Gerais state, with 89,5 ha in the municipality of Ritápolis, and exhibits phytophysiognomies of the Cerrado and Atlantic Forest. The climate is marked by mild summers and winter droughts (Köppen classification: Cwb), the average annual rainfall is about $1.400 \mathrm{~mm}$ and the average temperature ranges $19^{\circ} \mathrm{C}$ (Ferreira et al., 2016). Wasp sampling was conducted actively using insect nets (Souza \& Prezoto, 2006), totaling 40 effective hours in six non-consecutive days in February, March and June 2016.

Alto-Montana Private Natural Heritage Reserve (RPPN Alto-Montana, $22^{\circ} 21^{\prime} 55^{\prime \prime} \mathrm{S}, 44^{\circ} 48^{\prime} 32^{\prime \prime} \mathrm{W}$ ) spans 672 ha in the municipality of Itamonte and exhibits phytophysiognomies of the Atlantic and Araucaria Forests. The climate is marked by mild rainy summers and winter droughts (Köppen classification: Cwb), the average annual rainfall is about $1.749 \mathrm{~mm}$ and the temperature ranges $12-17^{\circ} \mathrm{C}$ (Cruz et al., 2014). Wasp sampling was conducted actively (Souza \& Prezoto, 2006) within 27 net-hours over a week in October 2015, and through attractive traps with sardine bait (Souza et al., 2015c) along nine altitudinal ranges between 1,335 $\mathrm{m}$ and 2,135 $\mathrm{m}$, with one bottle trap at every $100 \mathrm{~m}$ of altitude. The traps remained in the field for 72 hours, within 648 trap-hours, totaling 675 effective sampling hours.

Rio Machado Basin State Environmental Protection Area (APA Rio Machado, $21^{\circ} 44^{\prime} 40^{\prime \prime} \mathrm{S}, 45^{\circ} 58^{\prime} 31^{\prime \prime} \mathrm{W}$ ) spans 125,4 ha and exhibits phytophysiognomies of the Atlantic Forest. The climate is marked by dry winters and wet summers (Köppen classification: Cwa), the average annual rainfall is about $1.556 \mathrm{~mm}$ and the temperature ranges $9-29^{\circ} \mathrm{C}$ (Latuf et al., 2019). Wasps were sampled in the municipalities of Machado $\left(21^{\circ} 40^{\prime} 30^{\prime \prime} \mathrm{S}\right.$, $\left.45^{\circ} 55^{\prime} 12^{\prime \prime} \mathrm{W}\right)$, Poço Fundo ( $\left.21^{\circ} 46^{\prime} 51^{\prime \prime} \mathrm{S}, 45^{\circ} 57^{\prime} 54^{\prime \prime} \mathrm{W}\right)$ and Fama $\left(21^{\circ} 24^{\prime} 21^{\prime \prime} \mathrm{S}, 45^{\circ} 49^{\prime} 44^{\prime \prime} \mathrm{W}\right)$ in 16 non-consecutive days from September 2018 to April 2019. Wasp sampling was conducted actively (Souza \& Prezoto, 2006) seeking individuals and colonies, totaling 211 net-hours.

Serra de São José Environmental Protection Area (APA Serra de São José, $21^{\circ} 07^{\prime} 08.87^{\prime \prime} \mathrm{S}, 4^{\circ} 07^{\prime} 22.84^{\prime \prime} \mathrm{W}$ ) spans 4.758 ha and exhibits phytophysiognomies of the Cerrado and Atlantic Forest. The climate is marked by mild summers and winter droughts (Köppen classification: $(w b)$, the average annual rainfall is about $1.500 \mathrm{~mm}$ and the average temperature ranges $19-20^{\circ} \mathrm{C}$ (Henriques \& Cornelissen, 2019). Wasp sampling was conducted actively using insect nets (Souza \& Prezoto, 2006), totaling 46 effective hours on nine non-consecutive days in March, April, July and November 2016, February 2017 and January 2018, along seven altitudinal ranges between $800 \mathrm{~m}$ and 1,400 $\mathrm{m}$ in the campos rupestres areas, with sampling at every $100 \mathrm{~m}$ of altitude.

The social wasps were sacrificed in the field, placed in containers with information of date and area of sampling. They were later identified with the aid of specialists and deposited at the Biological Collection of Social Wasps of the Zoology Laboratory of the Federal Institute of Southern Minas (IFSULDEMINAS), Inconfidentes campus. Data from other studies carried out in different Conservation Units in the Minas Gerais state were also considered for the macroecological approach (Table 1).

\section{RESULTS AND DISCUSSION}

\section{Richness and distribution of social wasps in the four Conservation Units sampled in this study}

Thirty-five species of social wasps were registered for the APA Rio Machado, 19 for the APA Serra de São José, 14 for the FLONA Ritápolis and 10 for the RPPN Alto-Montana (Table 2). In the APA Serra de São José, four other spe- 
cies were registered for the first time in this Conservation Unit at intermediate and high altitudes of the campos rupestres: Agelaia vicina (Saussure 1854) (1,000, 1,300 and 1,400 m), Brachygastra lecheguana (Letreille 1824) $(1,400 \mathrm{~m})$ and Polistes pacificus Ducke 1918 (1,100 m); in addition, Mischocyttarus giffordi Raw, 1987 was reported in a semideciduous seasonal forest on this same mountain in 2018. The APA Serra de São José has potential to harbor a greater number of species, also because of the vegetation heterogeneity in other areas of the mountain. However, several negative anthropic influences such as fires, disordered tourism and pollution caused by it, the presence of cattle and the invasion of exotic species (eg. Poaceae, used as pasture) put this biodiversity at risk.

The variation in the social wasp richness for the four areas can be explained by several factors, such as

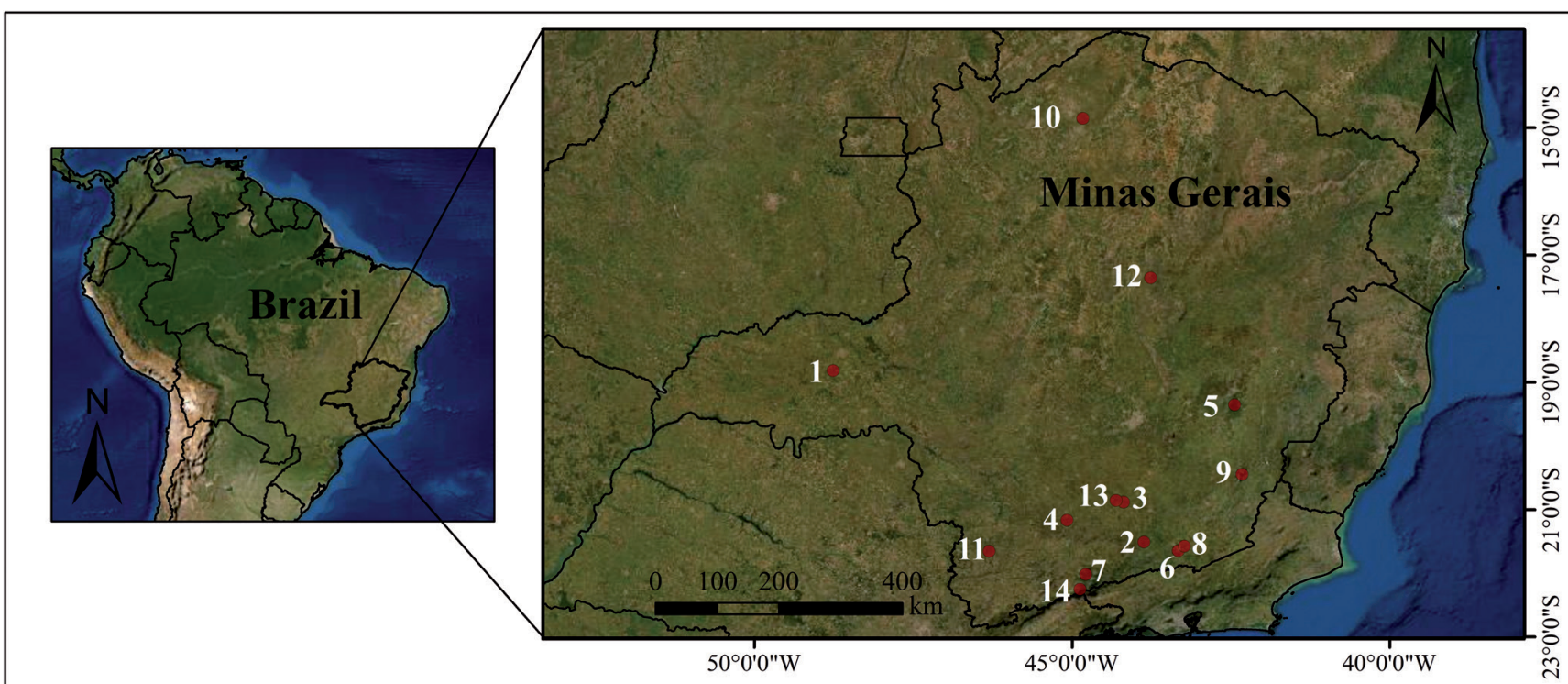

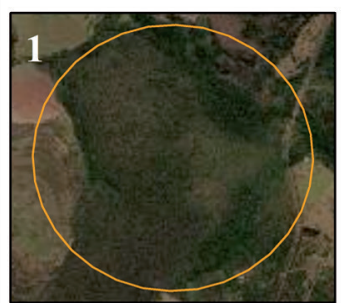
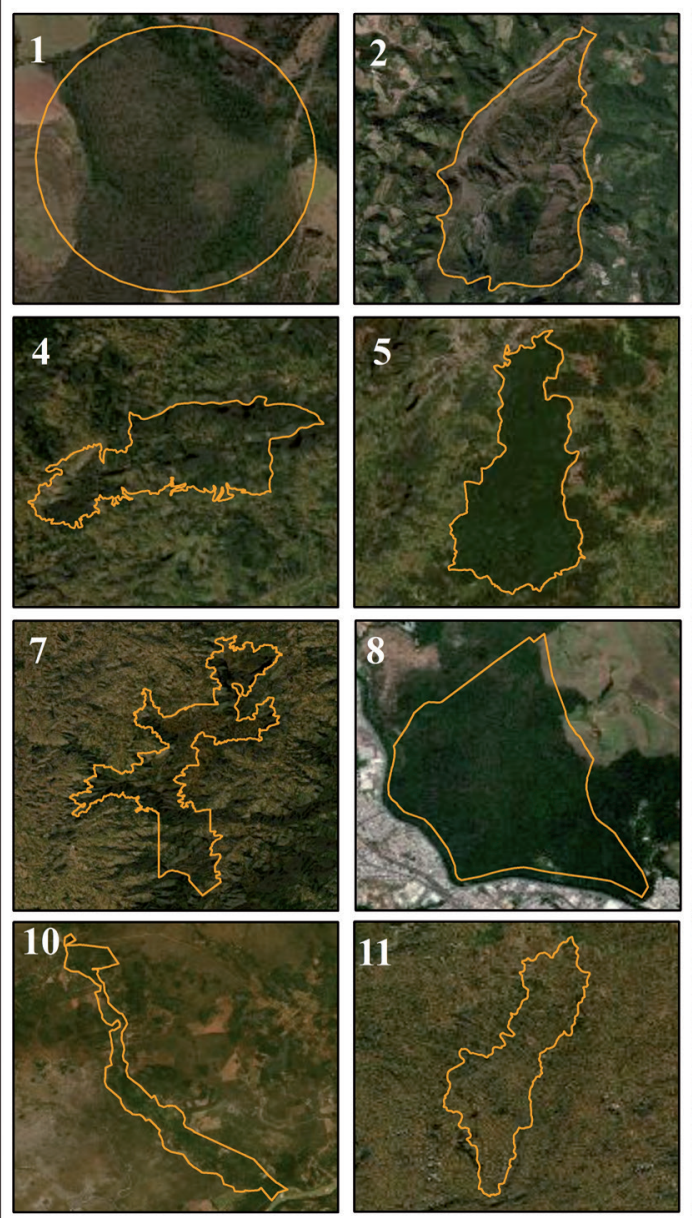

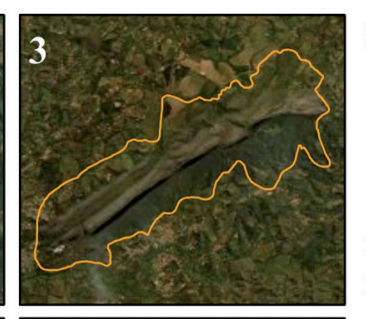

Social wasp richness in Conservation Units
in Minas Gerais state, Brazil

APA Serra de São José
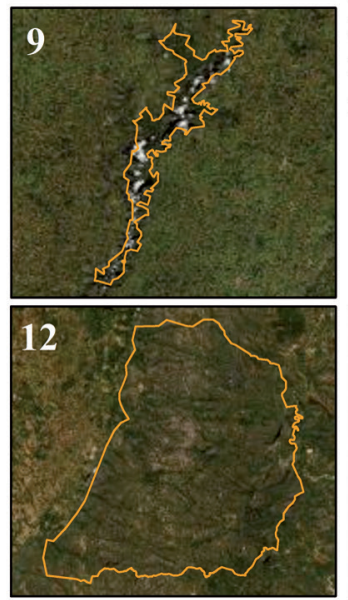

Site

$R B$ do Panga

PE Ibitipoca

RB Boqueirão

PE Rio Doce

PNM da Lajinha

PE Serra do Papagaio

APA Krambeck

PE Serra do Brigadeiro

1 RVS Rio Pandeiros

APA Rio Machado

12 PN Sempre-Vivas

13 FLONA Ritápolis

14 RPPN Alto-Montana

\section{Richness Exclusive spp.}

29

28

36

32

38

23

28

36

22

37

35

39

14

10
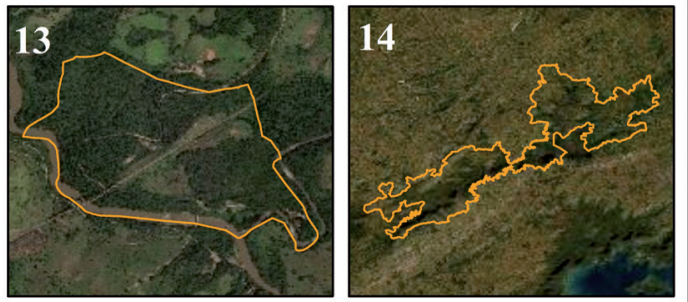

Figure 1. Geographic location of the sampled Conservation Units in the Minas Gerais state, southeastern Brazil, where social wasp inventories were carried out so far (maps at the top, Conservation Units are represented by the red points numbered from 1 to 14). The table on the right shows data of species richness and exclusive occurrence in each Conservation Unit. Aerial view of the Conservation Unit areas (satellite images 1-14). The numbers of map, table, and satellite images are corresponding. 
Table 1. Social wasp studies carried out in Conservation Units in Minas Gerais state, southeastern Brazil. UC = Conservation Units, FLONA Ritápolis = Ritápolis National Forest, RPPN Alto-Montana = Alto-Montana Private Natural Heritage Reserve, APA Rio Machado = Rio Machado Basin State Environmental Protection Area, APA Serra de São José = Serra de São José Environmental Protection Area, RB do Panga = Panga Biological Reserve, PE Ibitipoca $=$ Ibitipoca State Park, RB Boqueirão = Boqueirão Biological Reserve, PE Rio Doce $=$ Rio Doce State Park; PNM da Lajinha $=$ Lajinha Municipal Natural Park, PE Serra do Papagaio $=$ Serra do Papagaio State Park, APA Krambeck = Krambeck Environmental Protection Area, PE Serra do Brigadeiro = Serra do Brigadeiro State Park, RVS Rio Pandeiros $=$ Pandeiros River Wildlife Regufe, PN Sempre-Vivas = Sempre-Vivas National Park, SSF = Seasonal Semideciduous Forest, DOF = Dense Ombrophilous Forest, CR = Campos Rupestres, $C E=$ Cerrado, $\mathrm{RF}=$ Riparian Forest, $\mathrm{MF}=$ Mixed Forest, $\mathrm{AF}=$ Altitude Fields, $\mathrm{SDF}(\mathrm{DF})=$ Seasonal Deciduous Forest - Dry Forest.

\begin{tabular}{|c|c|c|c|c|}
\hline Studies & UC & Biome & Vegetation type & Richness \\
\hline Our study & FLONA Ritápolis & Atlantic forest & SSF & 10 \\
\hline Our study & RPPN Alto-Montana & Atlantic forest & DOF, SSF & 14 \\
\hline Our study & APA Rio Machado & Atlantic forest & SSF & 35 \\
\hline Our study, Souza et al., 2010 & APA Serra de São José & Cerrado/Atlantic forest & $C R$ & 36 \\
\hline Elpino-Campos et al., 2007 & RB do Panga & Cerrado & CE & 29 \\
\hline Prezoto \& Clemente, 2010, Souza et al., 2018 & PE Ibitipoca & Atlantic forest/Cerrado & CR, SSF, RF & 28 \\
\hline Simões et al., 2012 & RB Boqueirão & Cerrado & CE & 32 \\
\hline Souza et al., 2012 & PE Rio Doce & Atlantic forest & DOF, SSF & 38 \\
\hline Brugger, 2014 & PNM da Lajinha & Atlantic forest & SSF & 23 \\
\hline Souza et al., 2015b, 2018 & PE Serra do Papagaio & Atlantic forest & $\mathrm{MF}, \mathrm{AF}$ & 28 \\
\hline Barbosa, 2015 & APA Krambeck & Atlantic forest & SSF & 36 \\
\hline Souza et al., 2015a & PE Serra do Brigadeiro & Atlantic forest & SSF & 22 \\
\hline Brunismann et al., 2016 & RVS Rio Pandeiros & Cerrado/Atlantic forest & SDF (DF) & 37 \\
\hline Souza et al., 2020b & PN Sempre-Vivas & Cerrado & CE & 39 \\
\hline
\end{tabular}

the sampling effort and methodology, elevation, phytophysiognomy, ecosystem conservation degree and regeneration stage, in addition of the forest fragmentation and degradation effect. The sampling effort between the areas exhibits a marked difference, as observed in the APA Rio Machado, where were 211 nethours, and in the FLONA Ritápolis where 40 hours were carried out. However, the effort-hour was also proportional to the size difference of the sampled areas. In the APA Serra de São José, there was a total sampling effort of 168 net-hours, considering the sum of the hours of the previously published paper (Souza et al., 2010) and our study, and in the RPPN Alto-Montana, there were 27 net-hours and 648 trap-hours. However, even with the expressive number of hours invested in the passive method it was a little ineffective, because it registered the same four species already captured by active sampling. The sampling effort invested in each area may have impacted the number of registered species, as also observed in other studies (Souza \& Prezoto, 2006; Jacques et al., 2018; Somavilla et al., 2019), demonstrating how much the sampling effort can influence the richness recording.

A second factor that can influence the difference in richness between areas is the elevation, theme of some work with social wasps carried out in Brazil (Albuquerque et al., 2015; Souza et al., 2015a; Ribeiro et al., 2019). In the RPPN Alto-Montana, the sampling was carried out in nine altitudinal ranges ranging from 1,335 to $2,135 \mathrm{~m}$, while in the APA Serra de São José the altitudes vary from 800 to $1,400 \mathrm{~m}$, which can affect the distribution of social wasp communities. It is also important to consider that each community probably have different adaptive characteristics to each elevational gradient. The highest elevation in the APA Serra de São José is the lowest in the RPPN Alto-Montana, for example, where social wasp species adapted to higher altitudes on one mountain may not be the same as those on the other mountain, generating differences in the species composition and distribution across different gradients. Several species have restrictions to high altitudes, generated by the increase in climatic severity (eg. decrease in temperature, greater exposure to ultraviolet rays, greater wind speed), decrease in area, resources and primary productivity, absence or reduction of adaptative morphophysiological traits and even due to geographical isolation (Janzen, 1973, Lawton et al., 1987, Fernandes, 2016).

In addition to the factors mentioned, the area conservation and regeneration situation must also be considered (Souza et al., 2010; Clemente et al., 2019), as well as the habitat fragmentation degree (Bueno et al., 2019; Graça \& Somavilla, 2019) and the available substrates for nesting by social wasp species (Corbara et al., 2009; Souza et al., 2014; Francisco et al., 2018). Lawton (1983) and Santos et al. (2007) reported that environments with more complex structure enable the establishment and survival of more social wasp species. The vegetation exerts considerable influence on the social wasp communities, because it provides support for foundation of nests and food resources, and indirectly affects these communities by variations caused in temperature, air humidity and amount of ambient shadow (Santos et al., 2007; Milani et al., 2020). The social wasp species that nest only on certain conditions, select the locations of their nests by the vegetation density and types, whether it is open or closed, as well as the shape and arrangement of leaves and other plant structures (Machado, 1982; Santos \& Gobbi, 1998). It should also be considered, in a context of accelerated climate changes, generated by environmental degradation, that the small body size of wasps makes them a sensitive group to these variations (Deutsch et al., 2008). 


\section{Relevance of Conservation Units for species of social wasps}

There are 96 species of social wasps distributed in 14 Conservation Units in Minas Gerais state, which represents just about $10 \%$ of these areas in the state. This species number makes up about $90 \%$ of the 111 occurrences for the state (Souza et al., 2020a; Souza et al., 2020b), including Mischocyttarus garbei Zikán, 1935 sampled in the FLONA Ritápolis, recorded for the first time in the state. This species is restricted to the Atlantic Forest (Souza et al., 2020a), with occurrence records, until then, only for the states of Rio de Janeiro and Espírito Santo (Richards, 1978; Souza et al., 2015d). Three species, Mischocyttarus buysoni (Ducke, 1906), Polybia brunnea (Curtis, 1844) and Polybia emaciata (Saussure, 1854) are reported for the state (Richards, 1978), however there is no precise information regarding their distribution and occurrence (Souza et al., 2017; Souza et al., 2020a; Souza et al., 2020b). Thirty-four species occurring in Minas Gerais were sampled only in Conservation Units, which may be due to less sampling effort outside UCs in the state. Twenty-seven of the 34 species are exclusive to a single location and seven others are common to more than one (Table 3).

All these data evidences the relevance of the Conservation Units for the preservation of the social wasp populations in Minas Gerais state, especially four of them: the Serra do Papagaio State Park, the Rio Doce State Park, the Pandeiros River Wildlife Refuge and the APA Rio Machado. The Serra do Papagaio State Park, besides harboring an expressive richness of social wasps, it stands out for the first record of Mischocyttarus anthracinus Richards, 1945 unprecedented for Brazil, occurring until then only in Paraguay (Richards, 1978). This Conservation Unit also harbors a great butterfly (Oliveira et al., 2018) and harvestmen diversity (Ferreira et al., 2019), showing itself as an important refuge for several arthropod groups.

In the Rio Doce State Park, as already pointed out by Souza et al. (2017), the great richness and the large number of exclusive species could be a reflection of the climate, the great territorial extension, once this is the largest Conservation Unit of Minas Gerais state, and also of the large extension of conserved vegetation, that covers the largest portion of preserved Atlantic Forest of the state. Souza et al. (2012) showed that the social wasp richness in the area can reach 70 species, reinforcing how much this Conservation Unit is extremely biodiverse and important for the maintenance of these populations. The difference between the number of sampled and estimated species, pointed out by Souza et al. (2012), may be the result of the sampling difficulty in a high-canopy forest environment and by the camouflage of the nests in these environments (Jeanne \& Morgan, 1992), which justifies new studies that emphasize the canopy communities.

The Rio Pandeiros Wildlife Refuge shows itself as an important area because it harbors the second greatest richness among the Conservation Units listed. Additionally, we report the need for further studies in de-
Table 2. Species of social wasps sampled in Rio Machado Basin State Environmental Protection Area (APA Rio Machado), Serra de São José Environmental Protection Area (APA São José), Ritápolis National Forest (FLONA Ritápolis), and Alto-Montana Private Natural Heritage Reserve (RPPN Alto-Montana). $0=$ absence; $1=$ presence; ${ }^{*}=$ new record updating the inventory by Souza et al., 2010).

\begin{tabular}{|c|c|c|c|c|}
\hline \multirow{3}{*}{ Species } & \multicolumn{4}{|c|}{ Conservation Units } \\
\hline & APA & APA & FLONA & RPPN \\
\hline & $\begin{array}{c}\text { Rio } \\
\text { Machado }\end{array}$ & $\begin{array}{l}\text { São } \\
\text { José }\end{array}$ & Ritápolis & $\begin{array}{c}\text { Alto- } \\
\text { Montana }\end{array}$ \\
\hline Agelaia multipicta (Haliday, 1836) & 1 & 0 & 1 & 1 \\
\hline Agelaia vicina (Saussure, 1854) & 1 & $1^{*}$ & 1 & 1 \\
\hline Apoica gelida Van der Vecht, 1973 & 0 & 0 & 1 & 1 \\
\hline Apoica pallens (Fabricius, 1804) & 1 & 0 & 0 & 0 \\
\hline Brachygastra augusti (Saussure, 1854) & 1 & 0 & 0 & 0 \\
\hline Brachygastra lecheguana (Letreille, 1824) & 1 & $1^{*}$ & 0 & 0 \\
\hline Parachartergus fraternus (Griboldo, 1892) & 1 & 0 & 0 & 0 \\
\hline Parachartergus wagneri Buysson, 1904 & 1 & 0 & 0 & 0 \\
\hline Polybia chrysothorax (Lichtenstein, 1796) & 0 & 0 & 0 & 0 \\
\hline Polybia fastidiosuscula de Saussure, 1854 & 1 & 0 & 1 & 1 \\
\hline Polybia ignobilis (Haliday, 1836) & 1 & 1 & 1 & 0 \\
\hline Polybia jurinei de Saussure, 1854 & 1 & 0 & 0 & 0 \\
\hline Polybia minarum Ducke, 1906 & 1 & 0 & 0 & 0 \\
\hline Polybia occidentalis (Olivier, 1791) & 0 & 1 & 1 & 0 \\
\hline Polybia paulista H. von Ihering 1896 & 1 & 1 & 1 & 0 \\
\hline Polybia platycephala Richards, 1978 & 1 & 0 & 1 & 0 \\
\hline Polybia punctata du Buysson, 1907 & 1 & 0 & 0 & 1 \\
\hline Polybia scutelaris (White, 1841) & 1 & 1 & 1 & 0 \\
\hline Polybia sericea (0livier, 1791) & 1 & 1 & 0 & 0 \\
\hline Protonectarina sylveirae (Saussure, 1854) & 1 & 1 & 0 & 0 \\
\hline Protopolybia sedula (Saussure, 1854) & 1 & 0 & 0 & 1 \\
\hline Pseudopolybia vespiceps (Saussure, 1854) & 1 & 0 & 0 & 0 \\
\hline Synoeca cyanea (Fabricius, 1775) & 1 & 1 & 0 & 1 \\
\hline Polistes actaeon (Haliday, 1836) & 1 & 0 & 0 & 0 \\
\hline Polistes bicolor Fox, 1898 & 1 & 0 & 0 & 0 \\
\hline Polistes billardieri Saussure, 1853 & 0 & 1 & 0 & 0 \\
\hline Polistes cinerascens Saussure, 1854 & 1 & 1 & 0 & 1 \\
\hline Polistes davillae Richards, 1978 & 0 & 1 & 1 & 0 \\
\hline Polistes ferreri Saussure, 1853 & 1 & 1 & 0 & 0 \\
\hline Polistes pacificus Ducke, 1918 & 0 & $1^{*}$ & 0 & 0 \\
\hline Polistes simillimus Zikán, 1951 & 1 & 1 & 0 & 0 \\
\hline Polistes subsericius Saussure, 1854 & 1 & 1 & 0 & 0 \\
\hline Polistes versicolor (0livier, 1791) & 1 & 0 & 1 & 0 \\
\hline Mischocyttarus cassununga (R. von Ihering, 1903) & 1 & 0 & 0 & 0 \\
\hline Mischocyttarus confusus Zikán, 1935 & 0 & 0 & 0 & 0 \\
\hline Mischocyttarus drewseni Saussure, 1857 & 1 & 1 & 1 & 1 \\
\hline Mischocyttarus garbei Zikán, 1935 & 0 & 0 & 1 & 0 \\
\hline Mischocyttarus giffordi Raw, 1987 & 1 & $1^{*}$ & 0 & 0 \\
\hline Mischocyttarus ignotus Zikán, 1949 & 1 & 0 & 0 & 0 \\
\hline Mischocyttarus interjectus Zikán, 1935 & 1 & 0 & 0 & 0 \\
\hline Mischocyttarus latior (Fox, 1898) & 0 & 0 & 0 & 0 \\
\hline Mischocyttarus marginatus (Fox, 1898) & 0 & 0 & 0 & 0 \\
\hline Mischocyttarus mirificus Zikán, 1935 & 1 & 0 & 0 & 0 \\
\hline Mischocyttarus paraguaensis Zikán, 1935 & 0 & 0 & 1 & 0 \\
\hline Mischocyttarus parallellogramus Zikán, 1935 & 1 & 0 & 0 & 0 \\
\hline Mischocyttarus rotundicolis Cameron, 1912 & 0 & 1 & 0 & 0 \\
\hline Mischocyttarus socialis (Saussure, 1854) & 1 & 0 & 1 & 1 \\
\hline Mischocyttarus wagneri (Buysson, 1908) & 0 & 0 & 0 & 0 \\
\hline Mischocyttarus ypiraguensis da Fonseca, 1926 & 0 & 0 & 0 & 0 \\
\hline Total & 35 & 19 & 14 & 10 \\
\hline
\end{tabular}


Table 3. Rare social wasp species ( $1=$ presence; $0=$ absence) of the Conservation Units in the Minas Gerais state, southeastern Brazil. PERD = Rio Doce State Park; PESP = Serra do Papagaio State Park; PEIB = Ibitipoca State Park; PESB = Serra do Brigadeiro State Park; RVRP = Pandeiros River Wildlife Regufe; APASJ = Serra de São José Environmental Protection Area; APARM = Rio Machado Basin State Environmental Protection Area; PNSV = Sempre-Vivas National Park; APAK = Krambeck Environmental Protection Area; FLONAR = Ritápolis National Forest; PML = Lajinha Municipal Natural Park; RPPNAM = Alto-Montana Private Natural Heritage Reserve; $\mathrm{RBB}=$ Boqueirão Biological Reserve; $\mathrm{RBP}=$ Panga Biological Reserve.

\begin{tabular}{|c|c|c|c|c|c|c|c|c|c|c|c|c|c|c|}
\hline \multirow{2}{*}{ Species } & \multicolumn{14}{|c|}{ Conservation Units } \\
\hline & PE RD & PE SP & PEIB & PE SB & RV RP & APASJ & APA RM & RN SV & APA K & FLONAR & PML & RPPN AM & RB B & RB P \\
\hline Agelaia angulata & 1 & 0 & 0 & 0 & 0 & 0 & 0 & 0 & 0 & 0 & 0 & 0 & 0 & 0 \\
\hline Apoica thoraxica & 0 & 0 & 0 & 0 & 1 & 0 & 0 & 0 & 0 & 0 & 0 & 0 & 0 & 0 \\
\hline Brachygastra moebiana & 0 & 0 & 0 & 0 & 1 & 0 & 0 & 0 & 0 & 0 & 0 & 0 & 0 & 0 \\
\hline Chartergellus communis & 0 & 0 & 0 & 0 & 1 & 0 & 0 & 0 & 0 & 0 & 0 & 0 & 0 & 1 \\
\hline Chartergus globiventris & 0 & 0 & 0 & 0 & 1 & 0 & 0 & 0 & 0 & 0 & 0 & 0 & 0 & 1 \\
\hline Epipona tatua & 1 & 0 & 0 & 0 & 0 & 0 & 0 & 0 & 0 & 0 & 0 & 0 & 0 & 0 \\
\hline Metapolybia cingulata & 1 & 0 & 0 & 0 & 1 & 0 & 0 & 0 & 0 & 0 & 0 & 0 & 0 & 0 \\
\hline Parachartergus pseudopicalis & 0 & 0 & 0 & 0 & 0 & 0 & 0 & 0 & 0 & 0 & 0 & 0 & 0 & 1 \\
\hline Parachartergus wagneri & 0 & 0 & 0 & 0 & 0 & 0 & 1 & 0 & 0 & 0 & 0 & 0 & 0 & 0 \\
\hline Parachartergus smithii & 0 & 0 & 0 & 0 & 1 & 0 & 0 & 0 & 0 & 0 & 0 & 0 & 0 & 0 \\
\hline Polybia dimidiata & 1 & 0 & 0 & 0 & 0 & 0 & 0 & 0 & 0 & 0 & 0 & 0 & 0 & 0 \\
\hline Polybia flaviforns hecuba & 0 & 1 & 0 & 0 & 0 & 0 & 0 & 0 & 0 & 0 & 0 & 0 & 0 & 0 \\
\hline Polybia lugrubis & 0 & 0 & 0 & 0 & 0 & 0 & 0 & 0 & 1 & 0 & 0 & 0 & 0 & 0 \\
\hline Polybia rejecta & 1 & 0 & 0 & 0 & 0 & 0 & 0 & 0 & 0 & 0 & 0 & 0 & 0 & 0 \\
\hline Polybia signata & 1 & 0 & 0 & 0 & 0 & 0 & 0 & 0 & 0 & 0 & 0 & 0 & 0 & 0 \\
\hline Synoeca surinama & 0 & 0 & 0 & 0 & 1 & 0 & 0 & 1 & 0 & 0 & 0 & 0 & 0 & 0 \\
\hline Polistes bicolor & 0 & 0 & 0 & 0 & 0 & 0 & 1 & 0 & 0 & 0 & 0 & 0 & 0 & 0 \\
\hline Polistes canadensis & 1 & 0 & 0 & 0 & 0 & 0 & 0 & 0 & 0 & 0 & 0 & 0 & 0 & 0 \\
\hline Polistes cavapytiformes & 1 & 0 & 0 & 0 & 0 & 0 & 0 & 0 & 0 & 0 & 0 & 0 & 0 & 0 \\
\hline Polistes davillae & 0 & 0 & 0 & 0 & 0 & 1 & 0 & 0 & 0 & 1 & 0 & 0 & 0 & 0 \\
\hline Polistes geminatus & 0 & 0 & 0 & 0 & 0 & 0 & 0 & 0 & 0 & 0 & 0 & 0 & 1 & 0 \\
\hline Polistes melanossoma & 1 & 0 & 0 & 0 & 0 & 0 & 0 & 0 & 0 & 0 & 0 & 0 & 0 & 0 \\
\hline Polistes occipitalis & 1 & 0 & 0 & 0 & 0 & 0 & 0 & 0 & 0 & 0 & 0 & 0 & 0 & 0 \\
\hline Mischocyttarus anthracinus & 0 & 1 & 0 & 0 & 0 & 0 & 0 & 0 & 0 & 0 & 0 & 0 & 0 & 0 \\
\hline Mischocyttarus annulatus & 1 & 0 & 0 & 0 & 0 & 0 & 0 & 0 & 0 & 0 & 0 & 0 & 0 & 0 \\
\hline Mischocyttarus bahiaensis & 1 & 0 & 0 & 0 & 0 & 0 & 0 & 0 & 0 & 0 & 0 & 0 & 0 & 0 \\
\hline Mischocyttarus bahiae & 1 & 0 & 0 & 0 & 0 & 0 & 0 & 0 & 0 & 0 & 0 & 0 & 0 & 0 \\
\hline Mischocyttarus frontalis & 1 & 0 & 0 & 0 & 0 & 0 & 0 & 0 & 0 & 0 & 0 & 0 & 0 & 0 \\
\hline Mischocyttarus garbei & 0 & 0 & 0 & 0 & 0 & 0 & 0 & 0 & 0 & 1 & 0 & 0 & 0 & 0 \\
\hline Mischocyttarus giffordi & 0 & 1 & 0 & 0 & 0 & 1 & 1 & 0 & 0 & 0 & 0 & 0 & 0 & 0 \\
\hline Mischocyttarus interjectus & 0 & 0 & 0 & 0 & 0 & 0 & 1 & 0 & 0 & 0 & 0 & 0 & 0 & 0 \\
\hline Mischocyttraus marginatus & 0 & 0 & 0 & 0 & 0 & 1 & 0 & 1 & 0 & 0 & 0 & 0 & 0 & 1 \\
\hline Mischocyttarus montei & 0 & 0 & 0 & 0 & 1 & 0 & 0 & 0 & 0 & 0 & 0 & 0 & 0 & 0 \\
\hline Mischocyttarus proximus & 0 & 1 & 0 & 0 & 0 & 0 & 0 & 0 & 0 & 0 & 0 & 0 & 0 & 0 \\
\hline Exclusive species & 13 & 3 & 0 & 0 & 4 & 0 & 3 & 0 & 1 & 1 & 0 & 0 & 1 & 1 \\
\hline Total richness & 38 & 28 & 28 & 22 & 37 & 35 & 35 & 39 & 36 & 14 & 23 & 10 & 32 & 29 \\
\hline
\end{tabular}

ciduous forests, also known as dry forests (Brunismann et al., 2016), as this is the only work that assesses the social wasp richness in this area, as well as in the entire northern region of the state. Dry forest constitutes a transition ecosystem for the Caatinga biome, where there were no studies on these insects up to now in Minas Gerais (Souza et al., 2017). There are few studies in Caatinga also for other states (Andena \& Carpenter, 2014; Somavilla et al., 2017), and this lack of information justifies other studies in Conservation Units that shelter this semi-arid ecosystem. The APA Rio Machado has 35 species of social wasps and, until now, three of which were sampled only in Conservation Units. These species were sampled in the region of the Poço Fundo municipality, where there is greater continuous vegetation cover, but which suffers from many anthropic disturbances, such as livestock, burning, deforestation, reduction of riparian forests and coffee monoculture. Another problem of this area is the reduced staff team of the Minas Gerais Forestry State Institute (IEF-MG) to inspect the entire area of $211.8 \mathrm{~km}^{2}$, comprising eleven municipalities in the region (Porto et al., 2019), which indicates a difficulty in performing more efficient protection.

One of the most worrying disturbance events that negatively affect terrestrial ecosystems is the fire, which is very common in Brazil both natural and (mostly) anthropogenic. According to Herawati \& Santoso (2011), forest fires cause various environmental problems that compromise biodiversity and its interactions, as well as increase $\mathrm{CO}^{2}$ emissions. In a study by Clemente et al. (2019) the influence of fire in a social wasp community in a Cerrado vegetation was assessed and a $33 \%$ reduction 
in richness and $49 \%$ in abundance after the fire disturbance was discovered, evidencing the great biodiversity loss caused by fires. Fires are one of the main and continuous threats to the Conservation Units purposes (Koproski et al., 2011). In Brazil, the causes of fires in Conservation Units have been mainly due to the incorrect use to renew pastures and clean up crop residues in neighboring properties and surrounding areas, which should act as a buffer zone to prevent impacts on biodiversity within the Conservation Unit area (Pereira et al., 2004). These factors demonstrate the need for greater investment in policies that aimed to reduce the impacts caused by fire and also its prevention, as well as the maintenance of brigade groups in the most favorable periods for fires. These methods are vital to protect all Conservation Units, but especially those listed in this study, as they all have a major negative impact on biodiversity due to fires.

Another relevant aspect is the concentration of studies in areas dominated by the Atlantic Forest biome over the Cerrado and Caatinga biomes (Fig. 1, Table 1). Souza et al. (2017) argued that this may be a reflection of logistics and cost issues, because the two main research centers dedicated to social wasp inventories in Minas Gerais state are in the Federal University of Juiz de Fora (UFJF) and the Federal Institute of the South of Minas (IFSULDEMINAS), which invest greater sampling efforts in the Atlantic Forest due to its geographical location.

Moreover, there are 11 social wasp species that occur in the state, but have not been registered in Conservation Units, where they would be more protected. Among these, we can mention Mischocyttarus paraguaensis Zikán 1949, Mischocyttarus artifex (Ducke, 1914), Mischocyttarus funerulus Zikán 1949 and Polistes pacificus flavopictus Ducke, 1918 occurring in Mata do Baú, the largest fragment of semideciduous seasonal forest in the Barroso municipality, southern center of Minas Gerais state, which harbors the greatest known social wasp richness of the state: 45 species (Souza \& Prezoto, 2006; Souza et al., 2010, Souza et al., 2017). In this fragment there is also an expressive Odonata richness, with newly discovered species (Souza et al., 2013; Machado \& Souza, 2014; Machado, 2015), and solitary wasps with unprecedented records for Brazil (Tanque et al., 2010), in addition to a great Orchidaceae richness (Menini-Neto et al., 2004). However, this area suffers from several anthropogenic disturbances, such as livestock, eucalyptus cultivation and fires (Souza, 2006), which represent a great threat to the environment integrity and the species preservation in the region.

In addition to the species occurring in the Barroso municipality, others are registered only outside the UCs. Among then, Mischocyttarus nomurae Richards, 1978 which also occurs in this biome areas in the Montes Claros municipality, in the north of Minas Gerais, as well as Metapolybia docilis Richards, 1978 (Souza et al., 2015c). Mischocyttarus mourei Zikán 1949 occurs in the region of Monte Verde district, an area of marked tourist flow, in the Camanducaia municipality (Abulquerque et al., 2015). Polybia bistriata (Fabricius, 1804) occurs on the campus of the Federal University of Lavras (UFLA), and in Cerrado enclaves associated with semideciduous forest in the Atlantic Forest domain in the south of the state (Jacques et al., 2018). Polyblia liliacea (Fabricius, 1804) occurs in eucalyptus monoculture regions in the east of the state, bordering the Rio Doce State Park (Silva-Filho et al., 2020). Mischocyttarus wygodzinskyi Zikán 1978, occurs in forest fragments of semideciduous seasonal forest, in the Inconfidentes municipality region (Bueno et al., 2019), where Polybia quadricinta Saussure, 1858 is also registered. All of these species registered outside Conservation Units are more vulnerable and their populations are at risk of reduction. This is because these Conservation Units are one of the most efficient tools for protecting the biota, as discussed by Drummond et al. (2005), who also recommends the creation of this conservation mechanism for the Barroso municipality.

Despite the social wasp studies are concentrated in the Atlantic Forest areas, it is still necessary to continue efforts in this extremely threatened and highly diverse biome due to a large number of exclusive species and also to the fact that it harbors more than half of the species of social wasps of the country (Souza et al., 2020a). In the Cerrado biome, only two Conservation Units had been sampled until 2017. More recently, other areas that are fully inserted in this biome were studied, such as the Sempre Vivas National Park (Souza et al., 2020b) and the Serra da Canastra National Park (Marcos Magalhães de Souza, personal communication, unpublished data). Considering the great extent of these two biomes in the Minas Gerais state and the number of Conservation Units not yet sampled in both, there is still a lack of studies in the protected areas of these global biodiversity hotspots (Siqueira et al., 2017; Steinke et al., 2018). For the Caatinga biome, it is urgent to carry out more studies, because although it harbors great biodiversity of different taxa (Gusmão et al., 2016), this biome has been suffering a continuous reduction of its area by different impacting agents. For this reason, Caatinga experiences increasing desertification, with consequent loss of habitats, species, and its interactions, so important for the ecosystem functioning (Araújo \& Sousa, 2011).

\section{CONCLUSIONS}

Conservation Units fulfill their purpose of protecting the social wasp diversity in Minas Gerais, as they harbor more than $90 \%$ of the species sampled in the state. However, there are still many of these protected areas in which the biodiversity of social wasps is unknown, as well as biomes that need further investigation on surveying species richness, such as the Cerrado and especially the Caatinga. There are new records in Conservation Units, such as Mischocyttarus garbei Zikán, 1935 sampled in the FLONA Ritápolis, recorded for the first time in the state, reinforcing the importance of new studies in these areas for the biodiversity knowledge. Four Conservation Units stand out for their richness and the number of exclusive species: the Rio Doce State Park, which needs a greater sampling effort; the Serra do Papagaio State 
Park, which suffers from frequent fires; the Rio Pandeiros Wildlife Refuge, which harbors dry forest vegetation and it is also in need of studies; and the APA Rio Machado, which suffers various anthropic disturbances. Finally, it is recommended the creation of a Conservation Unit in the Barroso municipality, which harbors some social wasp species that do not occur in protected areas and harbors a great richness of other insect groups.

\section{ACKNOWLEDGMENTS}

We thank Dr. Orlando Tobias Silveira (Emílio Goeldi Museum, Pará state) for the assistance in wasp species identification, MSc. Raúl Badillo Montaño (Inecol, Mexico) for cartographical assistance and Patrícia Pereira Gomes (IFPR, Campus Umuarama) for translation assistance. We thank SISBIO (licenses \#51941 and \#63914-1) and IEF (license \#062/2018) for research licenses, the Conservation Units administrators and staff for their support, nominally MSc. Juliana Lombello and the staff of the APA Rio Machado (Pedro and Fernando) for field assistance. We thank IFSULDEMINAS and UFSJ for logistics. Glauco Cassio de Sousa Oliveira was supported by FAPEMIG and Nathália Ribeiro Henriques was supported by CAPES through a graduate scholarship.

\section{AUTHORS' CONTRIBUTIONS STATEMENT}

Master G.C.S.O.: Lead author and responsible for all phases of this study. Master N.R.H.: Lead author and responsible for all phases of this study. PhD M.A.C.: Lead author and responsible for all phases of this study. PhD M.M.S.: Responsible advisor, author and responsible for all phases of this study.

\section{REFERENCES}

Albuquerque, C.H.B.; Souza, M.M. \& Clemente, M.A. 2015. Comunidade de vespas sociais (Hymenoptera, Vespidae) em diferentes gradientes altitudinais no sul do estado de Minas Gerais, Brasil. Biotemas, 28: 131-138.

Andena, S.R. \& Carpenter, J.M. 2014. Checklist das espécies de Polistinae (Hymenoptera, Vespidae) do semiárido brasileiro. In: Bravo, F. \& Calor, A. (Eds.). Artrópodes do Semiárido: Biodiversidade e Conservação. Feira de Santana, Printmidia. p. 169-180.

Araújo, C.S.F. \& Sousa, A.N. 2011. Estudo do processo de desertificação na Caatinga: uma proposta de educação ambiental. Ciência \& Educação, Bauru, 17(4): 975-986.

Barbosa, B.C. 2015. Vespas sociais (Vespidae: Polistinae) em fragmento urbano: riqueza, estratificação e redes de interação. (Masters Dissertation). Universidade Federal de Juiz de Fora. 60p.

Barbosa, B.C.; Detoni M.; Maciel T.T. \& Prezoto F. 2016. Studies of social wasp diversity in Brazil: Over 30 years of research, advancements and priorities. Sociobiology, 63(3): 858-880.

Brooks, T.M.; Mittermeier, R.A.; Mittermeier, C.G.; Fonseca, G.A.B.; Rylands, A.B.; Konstant, W.R.; Flick, P.; Pilgrim, J.; Oldfield, S.; Magin, G. \& HiltonTaylor, C. 2002. Habitat loss and extinction in the hotspots of biodiversity. Conservation Biology, 16(4): 909-923.
Brugger, B.P. 2014. Diversidade de vespas sociais em um fragmento urbano. (Masters Dissertation). Universidade Federal de Juiz de Fora. 46p.

Brunismann, A.G.; Souza, M.M.; Pires, E.P.; Coelho, E.L. \& Milani, L.R. 2016. Social wasps (Hymenoptera: Vespidae) in deciduous seasonal forest in Southeastern Brazil. Journal of Entomology and Zoology Studies, 4: 447-452.

Bueno, E.T.; Souza, M.M. \& Clemente, M.A. 2019. The effect of forest fragmentation on Polistinae. Sociobiology, 66(3): 508-514.

Carpenter, J.M. 2004. Synonymy of the genus Marimbonda Richards, 1978, with Leipomeles mobius, 1856 (Hymenoptera: Vespidae: Polistinae), and a new key to the genera of paper wasps of the new world. American Museum Novitates, 3456: 1-16.

Clemente, M.A.; Ceridório, H.F.; Mendes, D.R.S.; Guevara, R.; Silveira, 0.T.; Giannotti, E.; Moleiro, H.R. \& Vieira, K.M. 2019. Impacts of fire in social wasps community in an area of regenerating Brazilian Savanna. Sociobiology, 66(4): 582-591.

Corbara, B.; Carpenter, J.M.; Céréghino, R.; Leponce, M.; Gibernau, M. \& Dejean, A. 2009. Diversity and nest site selection of social wasps along Guianese forest edges: assessing the influence of arboreal ants. Comptes Rendus Biologies, 332: 470-479.

Cruz, B.P.; Castro, E.M.; Cardoso, M.G.; Souza, K.F.; Machado, S.M.F.; Pompeu, P.V. \& Fontes, M.A.L. 2014. Comparison of leaf anatomy and essential oils from Drimys brasiliensis Miers in a montane cloud forest in Itamonte, MG, Brazil. Botanical Studies, 55: 1-14.

Deutsch, C.A.; Tewksbury, J.J.; Huey, R.B.; Sheldon, K.S.; Ghalambor, C.K.; Haak, D.C. \& Martin, P.R. 2008. Impacts of climate warming on terrestrial ectotherms across latitude. Proceeding of the National Academy of Sciences of the United States of America, 105(18): 6668-6672.

Drummond, G.M.; Martins, C.S.; Machado, A.B.M.; Sebaio, F.A. \& Antonini, Y. 2005. Biodiversidade em Minas Gerais: um atlas para sua conservação, 2a ed. Belo Horizonte, Fundação Biodiversitas. 222p.

Elpino-Campos, A.; Del-Claro, K. \& Prezoto, F. 2007. Diversity of social wasps (Hymenoptera: Vespidae) in Cerrado fragments of Uberlândia, Minas Gerais state, Brazil. Neotropical Entomology, 36(5): 685-692.

Fernandes, G.W. 2016. Ecology and conservation of mountaintop grasslands in Brazil. Switzerland, Springer. 567p.

Ferreira, A.C.; Figueiredo, M.A.; Salvio, G.M.M.; Fernandes, B.H. \& Rocha, L.C. 2016. Estudos Geoecológicos Aplicados ao Manejo da Trilha das Macaúbas na Floresta Nacional de Ritápolis, Minas Gerais. Caderno de Geografia, 26: 714-736.

Ferreira, A.S.; Pinheiro, I.L.C. \& Souza, M.M. 2019. Opiliones (Arachnida) in a mixed forest in southern Minas Gerais state, Brazil. Journal of Entomology and Zoology Studies, 7(5): 666-671.

Francisco, G.S.; Souza, M.M.; Clemente, M.A. \& Brunismann, A.G. 2018. Substrato vegetal utilizado para nidificação de vespas sociais (Hymenoptera, Vespidae) em Floresta Decidual. Revista Agrogeoambiental, 10: 35-45.

Graça, M.B. \& Somavilla, A. 2019. Effects of forest fragmentation on community patterns of social wasps (Hymenoptera: Vespidae) in Central Amazon. Austral Entomology, 58(3): 657-665.

Gusmão, L.F.P.; Queiroz, L.P.; Quijano, F.R.B.; Juncá, F.A.; Oliveira, R.P. \& Baseia, I.G. 2016. Caatinga: Diversidade na adversidade do Semiárido brasileiro. In: Peixoto, A.L.; Luz, J.R.P. \& Brito, M.A. (Eds.). Conhecendo a biodiversidade. Brasília, MCTIC/CNPq/PPBio. p. 101-111.

Henriques, N.R. \& Cornelissen, T. 2019. Wing asymmetry of a butterfly community: is altitude a source of stress? Community Ecology, 20(3): 252-257.

Herawati, H. \& Santoso, H. 2011. Tropical forest susceptibility to and risk of fire under changing climate: a review of fire nature, policy and institutions in Indonesia. Forest Policy and Economics, 13: 227-233. 
Instituto Estadual de Florestas (IEF). 2019. Unidades de Conservação. Available: http://www.ief.mg.gov.br/unidades-de-conservacao. Access: 23/06/2020.

Instituto Socioambiental (ISA). 2020. Unidades de Conservação no Brasil. Available: https://uc.socioambiental.org/mapa. Access: 23/06/2020.

Jacques, G.C.; Pires, P.; Hermes, M.G.; Faria, L.D.B.; Souza, M.M. \& Silveira, L.C.P. 2018. Evaluating the efficiency of different sampling methods to survey social wasps (Vespidae: Polistinae) in an anthropized environment. Sociobiology, 65(3): 515-523.

Janzen, D.H. 1973. Sweep samples of tropical foliage insects: effects of seasons, vegetation types, elevations, time of day, and insularity. Ecology Press, 54(3): 687-708.

Jeanne, R.L. \& Morgan, R.C. 1992. The influence of temperature on nest size, choice and reproductive strategy in temperate zone Polistes wasp. Ecological Entomology, 17: 135-141.

Koproski, L.; Ferreira, M.P.; Goldammer, J.G. \& Batista, A.C. 2011. Modelo de zoneamento de risco de incêndios para unidades de conservação brasileiras: 0 caso do Parque Estadual do Cerrado (PR). Floresta, 41: 551-562.

Latuf, M.0.; Musselli, D.G.; Chinen, H.S.S. \& Carvalho, P.H.S. 2019. Aporte sedimentar em suspensão na bacia do rio Machado, sul de Minas Gerais. Caderno de Geografia, 29: 16-35.

Lawton, J.H. 1983. Plant architecture and the diversity of phytophagous insects. Annual Review of Entomology, 28: 23-39.

Lawton, J.H.; MacGarvin, M. \& Heads, P.A. 1987. Effects of altitude on the abundance and species richness of insect herbivores on bracken. Journal of Animal Ecology, 56: 147-160.

Machado, A. 2015. Heteragrion thais sp. nov. from the Atlantic Forest of Brazil (Odonata: Heteragrionidae). Odonatologica, 44(3): 391-396.

Machado, A.B.M. \& Souza, M.M. 2014. A remarkable new species of Heteragrion from Brazil (Odonata Megapodagrionidae). International Journal of Odonatology, 17: 95-99.

Machado, V.L.L. 1982. Plants which supply "hair" material for nest building of Protopolybia sedula (Saussure, 1984). In: Jaisson, P. (Ed.). Social insects in tropics. Paris, University Paris-Nord. p. 189-192.

Menini-Neto, L.; Assis, L.C.S. \& Forzza, R.C. 2004. A família Orchidaceae em um fragmento de floresta estacional semidecidual no município de Barroso, Minas Gerais, Brasil. Lundiana, 5: 9-27.

Milani, L.R.; Jacques G.C.; Clemente M.A; Coelho E.L. \& Souza M. 2020. Influências dos fragmentos florestais sobre a nidificação de vespas sociais (Hymenoptera, Vespidae) em cafeeiro. Revista Brasileira de Zoociências, 21: 1-12.

Ministério do Meio Ambiente (MMA). 2019. Áreas protegidas e Unidades de Conservação. Available: https://www.mma.gov.br/areas-protegidas. html?view=default. Access: 22/06/2020.

Oliveira, L.A.; Milani, L.R. \& Souza, M.M. 2018. Riqueza de borboletas (Lepidoptera) no Parque Estadual da Serra do Papagaio, sul de Minas Gerais, Brasil. MG Biota, 11: 5-21.

Pereira, C.A.; Fiedler, N.C. \& Medeiros, M.B. 2004. Análise de ações de prevenção e combate aos incêndios florestais em unidades de conservação do cerrado. Floresta, 34: 95-100.

Porto, G.C.S.; Alves, F.D.; Bando, D.H.; Ribeiro, T.M. \& Silva, M.0. 2019. Notas sobre a formação territorial e dinâmica populacional dos municípios integrantes da APA do rio Machado, MG. Caderno de Geografia, 30: 72-88.

Prezoto, F. \& Clemente, M.A. 2010. Vespas sociais do Parque Estadual do Ibitipoca, Minas Gerais, Brasil. MG Biota, 3: 22-32.

Prezoto, F.; Nascimento, F.; Barbosa, B.C. \& Somavilla, A. 2020. Neotropical Social Wasps: Basic and applied aspects. Switzerland, Springer International Publishing Press. 300p.

Ribeiro, D.G.; Silvestre, R. \& Garcete-Barrett, B.R. 2019. Diversity of wasps (Hymenoptera: Aculeata: Vespidae) along an altitudinal gradient of
Atlantic Forest in Itatiaia National Park, Brazil. Revista Brasileira de Entomologia, 63: 22-29.

Richards, 0.W. 1978. The social wasps of the Americas excluding the Vespinae. London, British Museum (Natural History). 580p.

Santos, G.M.M. \& Gobbi, N. 1998. Nesting habits and colonial productivity of Polistes canadensis canadensis (L.) (Hymenoptera-Vespidae) in a caatinga area, Bahia State, Brasil. Journal of Advanced Zoology, 19: 63-69.

Santos, G.M.M.; Bichara, F.C.C.; Resende, J.J.; Cruz, J.D.D. \& Marques, 0.M. 2007. Diversity and community structure of social wasps (Hymenoptera: Vespidae) in three ecosystems in itaparica island, Bahia State, Brazil. Neotropical Entomology, 36: 180-185.

Schiavetti, A.; Manz, J.; Santos, C.Z.; Magro, T.C. \& Pagani, M.I. 2013. Marine protected areas in Brazil: An ecological approach regarding the large marine ecosystems. Ocean \& Coastal Management, 76: 96-104.

Silva-Filho, R.; Brugger, B.P.; Zanuncio, J.C. \& Cassino, P. 2020. Social wasps in exotic forest planting and Atlantic rainforest in the Neotropical region. Sociobiology, 67(2): 308-311.

Simões, M.H.; Cuozzo, M.D. \& Friero-Costa, F.A. 2012. Diversity of social wasps (Hymenoptera, Vespidae) in Cerrado biome of the southern of the state of Minas Gerais, Brazil. Iheringia, Serie Zoologia, 102(3): 292-297.

Siqueira, M.N.; Castro, S.S.; Morais, A.R. \& Faria, K.M.S. 2017. Woody plant community structure in "Dense Cerrado" fragments in the Upper Basin of the Araguaia River (Central Brazil): relationship with habitat loss and geographical distance. Brazilian Journal of Botany, 40: 717-725.

Somavilla, A.; Moraes-Junior, R.N.M. \& Rafael, J.A. 2019. Is the social wasp fauna in the tree canopy different from the understory? Study of a particular area in the Brazilian Amazon Rainforest. Sociobiology, 66: 179-185.

Somavilla, A.; Oliveira, M.L. \& Rafael, J.A. 2017. Social wasps (Vespidae: Polistinae) from two national parks of the Caatinga biome, in Brazil. Sociobiology, 64(3): 334-338.

Souza, M.M. 2006. Barroso, uma história de desmatamentos e de esforços atuais para conservação. Vertentes, 27: 16-26.

Souza, M.M. \& Prezoto, F. 2006. Diversity of social wasps (Hymenoptera: Vespidae) in semideciduous forest and cerrado (Savanna) regions in Brazil. Sociobiology, 47: 135-147.

Souza, M.M.; Brunismann, A.G. \& Clemente, M.A. 2017. Species composition, relative abundance and distribution of social wasps fauna on different ecosystems. Sociobiology, 64(4): 456-465.

Souza, M.M.; Clemente, M.A. \& Milani, L.R. 2018. Inventário de vespas sociais (Hymenoptera, vespidae) dos Parques Estaduais Serra do Papagaio e do Ibitipoca, Sudeste do Brasil. MG Biota, 11: 32-42.

Souza, M.M.; Teofilo-Guedes, G.S.; Milani, L.R.; Souza, A.S.B. \& Gomes, P.P. 2020a. Social wasps (Vespidae: Polistinae) from the Brazilian Atlantic Forest. Sociobiology, 67: 1-12.

Souza, M.M.; Guedes, G.T.; Bueno, E.T.; Milani, L.R. \& Souza, A.S.B. 2020b. Social Wasps (Hymenoptera, Polistinae) from the Brazilian Savanna. Sociobiology, 67: 129-138.

Souza, M.M.; Ladeira, T.E.; Assis, N.R.G.; Elpino-Campos, A.; Carvalho, P. \& Louzada, J. 2010. Ecologia de vespas sociais (Hymenoptera, Vespidae) no Campo Rupestre na Área de Proteção Ambiental, APA, São José, Tiradentes, MG. MG Biota, 3: 15-30.

Souza, M.M.; Pires, E.P.; Silva-Filho, R. \& Ladeira, T.E. 2015a. Community of social wasps (Hymenoptera: Vespidae) in areas of semideciduous seasonal montane forest. Sociobiology, 62(4): 598-603.

Souza, M.M.; Silva, H.N.M.; Dallo, J.B.; Martins, L.F.; Milani, L.R. \& Clemente, M.A. 2015b. Biodiversity of Social Wasps (Hymenoptera: Vespidae) at Altitudes Above 1600 Meters in the Parque Estadual da Serra do Papagaio, State of Minas Gerais, Brazil. EntomoBrasilis, 8: 174-179. 
Souza, M.M.; Perillo, L.N.; Barbosa, B.C. \& Prezoto, F. 2015c. Use of flight interception traps of Malaise type and attractive traps of social wasps record (Vespidae: Polistinae). Sociobiology, 62(4): 450-456.

Souza, M.M.; Pires, E.P.; Eugênio, R. \& Silva-Filho, R. 2015d. New Occurrences of Social Wasps (Hymenoptera: Vespidae) in Semideciduous Seasonal Montane Forest and Tropical Dry Forest in Minas Gerais and in the Atlantic Forest in the State of Rio de Janeiro. EntomoBrasilis, 8: 65-68.

Souza, M.M.; Pires, P.; Elpino-Campos, A. \& Louzada, J. 2014. Nesting of social wasps (Hymenoptera: Vespidae) in a riparian forest of Rio das Mortes in southeastern Brazil. Acta Scientiarum. Biological Sciences, 36: 189-196.

Souza, M.M.; Pires, P.; Ferreira, M.; Ladeira, T.E.; Pereira, M.C.S.A.; ElpinoCampos, A. \& Zanuncio, J.C. 2012. Biodiversidade de vespas sociais
(Hymenoptera: Vespidae) do Parque Estadual do Rio Doce, Minas Gerais, Brasil. MG Biota, 5: 4-19.

Souza, M.M.; Souza, B.; Pereira, M.C.S.A. \& Machado, A.B.M. 2013. List of Odonates from Mata do Baú, Barroso, Minas Gerais Brazil. Check List, 9(6): 1367-1370.

Steinke, V.A.; Barbosa, S.M.S.; Mendes, V.J.M.; Zanatto, V.G.; Pessoa, G.E. \& Bayma, G. 2018. Spatial analysis of federal protected areas and priority areas for biodiversity conservation in Brazil. Journal of Geographic Information System, 10: 718-734.

Tanque, R.L.; Kumagai, A.F. \& Souza, B. 2010. Novos registros de espécies de Pimplinae e Rhyssinae (Hymenoptera, Ichneumonidae) no Brasil. Revista Brasileira de Zoociências, 12: 103-106. 